\title{
Composition and distribution of Darwinulidae (Crustacea, Ostracoda) in the alluvial valley of the upper Paraná River, Brazil
}

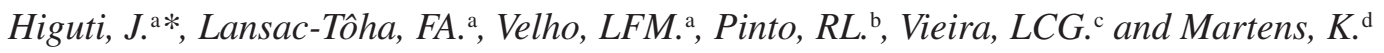 \\ ${ }^{a}$ Nupélia/PEA, Universidade Estadual de Maringá - UEM, \\ Av. Colombo, 5790, CEP 87020-900, Maringá, PR, Brazil \\ 'Pós-Graduação em Ciências (Zoologia), Universidade de São Paulo - USP, \\ Rua do Matão, Trav. 14, no. 101, CEP 05508-900, São Paulo, SP, Brazil \\ 'Pós-Graduação em Biologia (Ecologia), Campus Samambaia, Universidade Federal de Goiás - UFG, \\ CEP 74001-970, Goiânia, GO, Brazil \\ ${ }^{\mathrm{d}}$ Royal Belgian Institute of Natural Sciences, Vautierstraat 29, 1000, Brussels, Belgium \\ *e-mail: higuti@nupelia.uem.br \\ Received July 1, 2007 - Accepted October 5, 2007 - Distributed May 31, 2009
}

(With 5 figures)

\begin{abstract}
The occurrence and abundance of darwinulid ostracods, as well as environmental factors influencing these patterns, were investigated in the alluvial valley of the upper Paraná River. Ostracods were sampled from several substrates, like littoral sediments and pleuston, which included several aquatic macrophytes species, from 31 localities (lentic and lotic) belonging to different riverine systems. Eight darwinulid species were found, representing all genera from this family. Alicenula serricaudata, Vestalenula pagliolii, and Penthesilenula brasiliensis were the most common species. Cluster analysis based on the composition and abundance of darwinulid communities revealed the presence of five associations. Darwinula stevensoni, Vestalenula botocuda, and Penthesilenula aotearoa were almost exclusive to lotic environments. A Mantel multiple test showed that the occurrence and distribution of darwinulid ostracods were significantly related to types of habitat and systems, but not to abiotic variables. It thus seems that the hydrodynamic fluctuations of these environments are probably more important to darwinulid distribution than the limnological characteristics.
\end{abstract}

Keywords: Ostracoda, Darwinulidae, floodplain, Paraná River.

\section{Composição e distribuição de Darwinulidae (Crustacea, Ostracoda) no vale aluvial do alto rio Paraná, Brasil}

\begin{abstract}
Resumo
A ocorrência e abundância de ostrácodes darwinulídeos, bem como os fatores ambientais que influenciam estes padrões, foram investigadas no vale aluvial do alto rio Paraná. Os ostrácodes foram coletados em vários substratos, como sedimentos litorâneos e plêuston, o qual incluiu várias espécies de macrófitas aquáticas, de 31 ambientes (lênticos e lóticos) pertencentes a diferentes sistemas fluviais. Oito espécies de darwinulídeos foram encontradas, representando todos os gêneros desta família. Alicenula serricaudata, Vestalenula pagliolii e Penthesilenula brasiliensis foram as espécies mais comuns. A análise de agrupamento, baseada na composição e abundância das comunidades de darwinulídeos, revelou a presença de cinco associações. Darwinula stevensoni, Vestalenula botocuda e Penthesilenula aotearoa foram praticamente exclusivas de ambientes lóticos. O teste de Mantel múltiplo evidenciou que a ocorrência e distribuição de ostrácodes estiveram significantemente relacionadas aos tipos de hábitat e sistema, mas não às variáveis abióticas. Desta forma, parece que as flutuações hidrodinâmicas destes ambientes atuam mais fortemente na distribuição de darwinulídeos que as características limnológicas.
\end{abstract}

Palavras-chave: Ostracoda, Darwinulidae, planície de inundação, rio Paraná.

\section{Introduction}

The upper Paraná River floodplain has been the focus of intense limnological and ecological research over recent decades. Most studies have been carried out by researchers of the Núcleo de Pesquisas em Limnologia,

Ictiologia e Aquicultura (Nupélia) from the Universidade Estadual de Maringá, and focused on ecological aspects of several floodplain environments (Thomaz et al., 2004, among others). Although attention has been given to in- 
vertebrate diversity in this area (Velho et al., 2001; Higuti and Takeda, 2002; Lansac-Tôha et al., 2002), there are no published records about the ecology and distribution of ostracods in the alluvial valley of the upper Paraná River.

Darwinulid ostracods are small bivalved crustaceans (0.3-0.8 mm) inhabiting freshwater, brackish, terrestrial, and semi-terrestrial environments. Darwinulidae comprise less than $5 \%$ of the specific diversity of freshwater ostracod fauna (Martens, 1998). However, in the last decade, this family has received much attention from researchers, due to its recognition as a possible ancient asexual group (Butlin and Griffiths, 1993). Several biological and ecological (Van Doninck et al., 2003a, b), molecular (Schön et al., 2003; Martens et al., 2005), and taxonomical studies (Martens et al., 1997; Martens and Rossetti, 2002; Rossetti and Martens, 1996; 1998) have been conducted.

A particular biological aspect of the Darwinulidae is the fact that they have persisted over a geologically long period, at least 200 million years, without sexual reproduction, as evidenced by the absence of males in the fossil record (Martens et al., 2003), although recently three males of a new species of the genus Vestalenula Rossetti and Martens were found in Japan (Smith et al., 2006). Because of this particular biology, we performed a separate analysis of the representatives of this family in the Paraná floodplain. A general analysis of ostracod diversity in the alluvial valley of the upper Paraná River is presented elsewhere (Higuti et al., (in press.)).

In Brazil, studies of darwinulids are mainly related to taxonomical aspects (Pinto and Kotzian, 1961), including semi-terrestrial habitats (Pinto et al., 2003; 2004; 2005). Research focusing on the ecology of freshwater ostracods was performed by Würdig and Freitas (1988) and Rocha and Por (1998). Here, we describe the occurrence and abundance of darwinulid ostracods from the alluvial valley of the upper Paraná River, as well as the factors influencing their community structure.

\section{Material and Methods}

\subsection{Study area}

The upper Paraná River comprises a wide braided channel with an extensive floodplain and high sediment accumulation in its bed, creating sand bars and islands of diverse sizes (from hundreds of metres to several kilometres in length). The floodplain reaches $20 \mathrm{~km}$ in width and there are several secondary channels, lakes, and tributaries (including the Ivinheima and Baía Rivers) (Agostinho and Zalewski, 1996). Further away from the main channel, and not connected to it, is the Taquaruçu system which comprises exclusively closed lakes (Souza Filho and Stevaux, 2004). The stretch of the floodplain studied here is located between the coordinates $22^{\circ} 26^{\prime}, 22^{\circ} 56^{\prime} \mathrm{S}$ and $53^{\circ} 10^{\prime}, 53^{\circ} 40^{\prime} \mathrm{W}$ (Figure 1).

\subsection{Sampling and laboratory analysis}

Darwinulid ostracod fauna were collected during March, July and November 2004, in the alluvial valley of the upper Paraná River. From 48 habitats sampled, darwinulids were found in 31 ones belong to 4 fluvial systems (Paraná, Ivinheima, Baía, and Taquaruçu), 5 habitat types (closed lake, open lake, river, channel, and stream) and 8 substrate types (littoral = shallow benthic, Eichhornia crassipes (Mart.) Solms, Eichhornia azurea (Sw.) Kunth, Pistia stratiotes L., Salvinia spp, Hydrocotyle ranunculoides L.F., Oxycaryum cubense (Poeppig and Kunth), and mixed floating plants).

Ostracods were sampled using a rectangular net $(28 \mathrm{~cm} \times 14 \mathrm{~cm}$, mesh size c $160 \mu \mathrm{m})$ hauled close to the sediment-water interface for littoral collections. Floating vegetation was hand-collected, and roots were thoroughly washed in a bucket. The residues were washed in the same hand net.

In the laboratory, samples were washed over sieves ( 2 and $0.250 \mathrm{~mm}$ mesh) to facilitate sorting under a stereomicroscope. The material retained in the sieve with the smallest mesh was preserved in $70 \%$ alcohol.

Samples were fragmented using a Folsom fractioner, and $1 / 4$ of each sample was counted. However, species richness was estimated from the total sample. Valves and appendages of ostracods were examined using scanning electron microscopy and optical microscopy, respectively. Darwinulids were identified at the species level, using Rossetti and Martens (1996; 1998) and Pinto et al. (2003; 2004; 2005) as references.

For each sampling station, we recorded general aspects of the environment (types of substrate and habitat, connectivity degree, hydrodynamics) and limnological factors, such as $\mathrm{pH}$ (pHmeter-Digimed), electrical conductivity (conductivimeter-Digimed), dissolved oxygen, and water temperature (oxymeter-YSI). Macronutrients, calcium, and magnesium were quantified for the November 2004 sampling using atomic absorbance spectrometry. Sample collection and preservation to determine $\mathrm{Ca}$ and $\mathrm{Mg}$ concentrations followed the literature (Rainwater and Thatcher, 1960; Wagner, 1976).

\subsection{Data analyses}

Principal component analysis (PCA) was used to ordinate sampling stations/months based on abiotic limnological variables. One matrix (March/July) allowed analysis of water temperature, $\mathrm{pH}$, dissolved oxygen, and electrical conductivity. A second matrix (November) used the same four variable plus $\mathrm{Ca}$ and $\mathrm{Mg}$ concentrations. Data were previously log transformed, except for $\mathrm{pH}$.

A parametric ANOVA was performed to test for possible differences between the distribution of the three most abundant species (log transformed data), Alicenula serricaudata, Vestalenula pagliolii, and Penthesilenula brasiliensis, among types of system, habitats, and substrates. In the case of significant differences, a Tukey test was performed a posteri- 


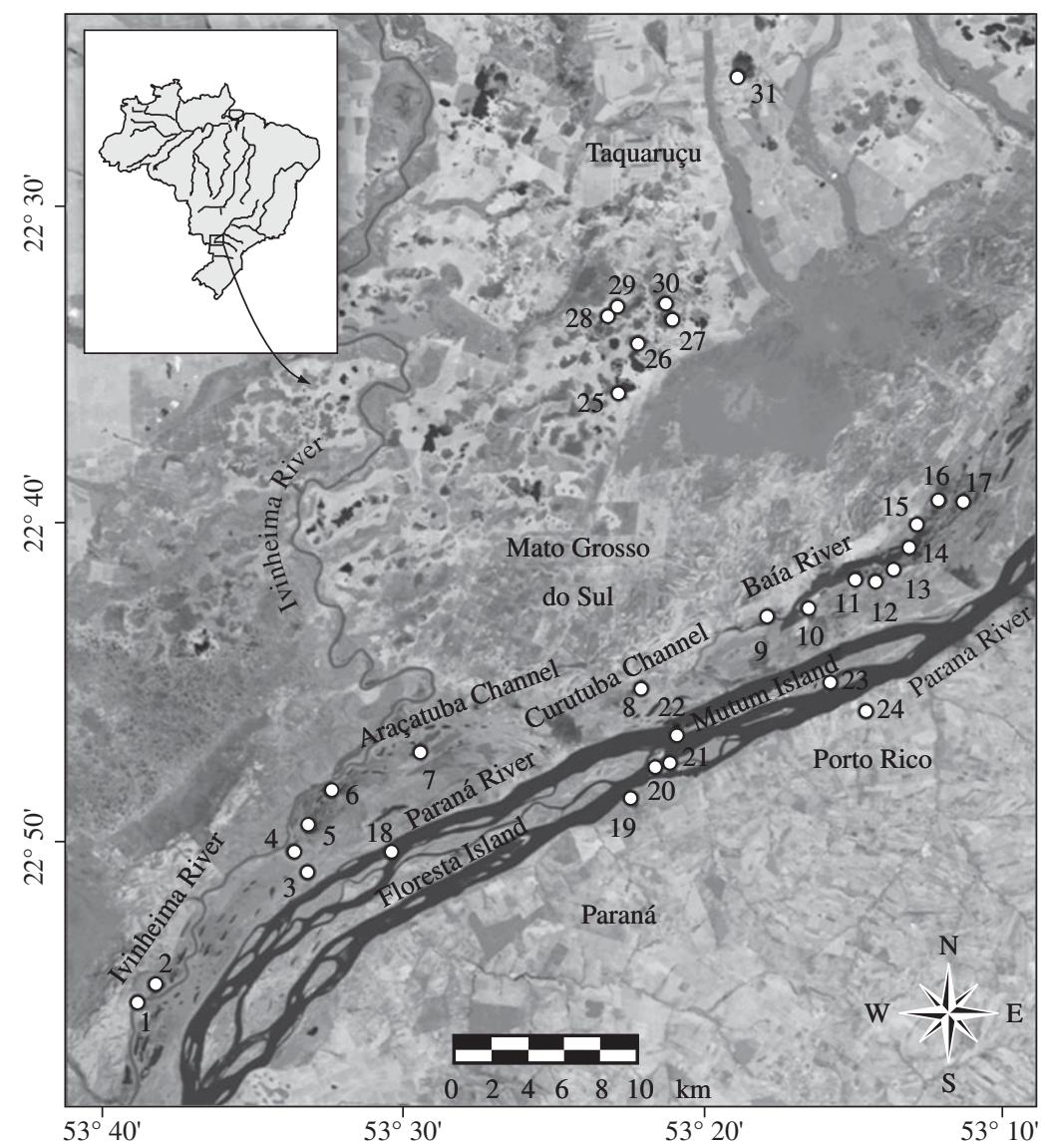

Figure 1. Satellite image (LANDSAT 7 - ETM 1999) of the 31 sampled localities in the alluvial valley of the upper Paraná River. Locality codes are shown in Table 1.

ori. When the homogeneity assumption required for ANOVA was not fulfilled, a non-parametric KruskalWallis test was used. For these analyses, the variables "stream" for habitat and "Oxycaryum cubense", "Hydrocotyle ranunculoides", and "Mixed floating plants" in the category substrate were excluded. For each of these variables, only a few cases were available in the dataset and these skewed the results considerably. A three-way ANOVA was not possible, as there were too many missing cells in the sampling design, e.g. system Taquaruçu only has the variable "closed lake" for habitat, and several floating plants (substrate) were absent in different habitat types.

The dissimilarity among samples pairs was calculated using the Bray-Curtis distance and UPGMA method, which places the samples into a hierarchical classification based on taxon composition and abundance.

A Mantel multiple test with 10,000 randomizations was performed to evaluate the influence of abiotic limnological variables (water temperature, $\mathrm{pH}$, dissolved oxygen, and electrical conductivity) and characteristics from each sampling site (type of system, habitat, and substrate) on darwinulid ostracod abundance. The distances among sampling units for biological data were measured using the Bray-Curtis dissimilarity coefficient; for abiotic limnological data, Euclidean distance was used.

\section{Results}

The study localities, types of system, habitats, and substrates, as well as the values for water temperature, $\mathrm{pH}$, dissolved oxygen, electrical conductivity, calcium, and magnesium are shown in Table 1.

The two first axes from principal component analyses, applied to matrices of abiotic limnological data from March/July (Figure 2a) and November (Figure 2b), explained $83.13 \%$ (axis $1=52.92 \%$ and axis $2=30.21 \%$ ) and $78.89 \%$ (axis $1=53.8 \%$ and axis $2=25.09 \%$ ) of total data variability, respectively. The lakes from the Taquaruçu system were distinguished from the other systems in March/July through principal component axis 1, due to lower values of temperature, electrical conductivity, and $\mathrm{pH}$. Dissolved oxygen was positively correlated to principal component 2 . In this case, we observed that the lakes of the Taquaruçu system, as well as the channels, rivers, and streams, have more oxygenated water; 
Table 1. Geographical locations and limnological characteristics (mean and standard deviation) of the alluvial valley of the upper Paraná River during the study period. Single values for abiotic variables mean that darwinulids were found in only one sampling period.

\begin{tabular}{|c|c|c|c|c|c|c|c|c|c|}
\hline $\begin{array}{c}\text { Locality } \\
\text { name }\end{array}$ & System & Habitat & Substrate & WT $\left({ }^{\circ} \mathbf{C}\right)$ & $\begin{array}{c}\text { EC } \\
\left(\mu \text { S.cm }{ }^{-1}\right) \\
\end{array}$ & pH & $\begin{array}{c}\text { DO } \\
\left(\mathrm{mg} \cdot \mathrm{L}^{-1}\right) \\
\end{array}$ & $\begin{array}{c}\mathrm{Ca} \\
\left(\mathbf{m g} \cdot \mathbf{L}^{-1}\right) \\
\end{array}$ & $\begin{array}{c}\mathrm{Mg} \\
\left(\mathrm{mg} \cdot \mathbf{L}^{-1}\right)\end{array}$ \\
\hline 1. Ivinheima & I & $\mathrm{Ri}$ & $\begin{array}{c}\mathrm{Ec}, \mathrm{Hr}, \\
\mathrm{Sa}\end{array}$ & $28.2 \pm 3.3$ & $43.9 \pm 3.7$ & $6.7 \pm 0.5$ & $6.2 \pm 0.4$ & 4.55 & 2.3 \\
\hline 2. Peroba & I & $\mathrm{Ol}$ & Ec & $28.5 \pm 4.0$ & $35.4 \pm 10.3$ & $6.3 \pm 0.7$ & $5.9 \pm 0.4$ & 2.92 & 1.61 \\
\hline 3. Ipoitã & I & $\mathrm{Ch}$ & $\mathrm{Ea}$ & 30.3 & 60.6 & 8.6 & 8 & nd & nd \\
\hline 4. Boca do Ipoitã & I & $\mathrm{Ol}$ & Ec & 25.7 & 41.8 & 5.8 & 3.5 & 4.32 & 2.14 \\
\hline 5. Patos & I & $\mathrm{Ol}$ & $\mathrm{Ec}$ & 26 & 48.2 & 5.4 & 2.7 & 5.74 & 2.16 \\
\hline 6. Capivara & I & $\mathrm{Cl}$ & $\mathrm{Li}$ & 27.2 & 55.9 & 5.4 & 0.6 & 8.27 & 2.53 \\
\hline 7. Jacaré & I & $\mathrm{Cl}$ & Ps & 28.5 & 35.4 & 4.7 & 4.1 & 4.93 & 1.87 \\
\hline 8. Curutuba & B & $\mathrm{Ch}$ & $\mathrm{Ps}, \mathrm{Sa}$ & 26.1 & 35.5 & 5.2 & 4.2 & 2.10 & 0.98 \\
\hline 9. Guaraná & $\mathrm{B}$ & $\mathrm{Ol}$ & Ps & 27.4 & 40.5 & 5.2 & 3.3 & 3.04 & 1.45 \\
\hline 10. Fechada & B & $\mathrm{Cl}$ & $\mathrm{Li}, \mathrm{Ps}, \mathrm{Ea}$ & $26.7 \pm 1.9$ & $29.8 \pm 3.9$ & $5.6 \pm 0.9$ & $4.0 \pm 2.4$ & 2.21 & 1.04 \\
\hline $\begin{array}{l}\text { 11. Pousada das } \\
\text { Garças }\end{array}$ & B & $\mathrm{Cl}$ & $\mathrm{Ec}$ & 26.3 & 29.7 & 5.5 & 3.9 & 2.41 & 1.34 \\
\hline 12. Porcos & $\mathrm{B}$ & $\mathrm{Ol}$ & $\mathrm{Ec}$ & $28.7 \pm 1.3$ & $41.2 \pm 0.1$ & $5.8 \pm 0.4$ & $3.8 \pm 0.4$ & 3.65 & 1.66 \\
\hline 13. Aurélio & B & $\mathrm{Cl}$ & $\mathrm{Li}$ & 28 & 36 & 6 & 3 & nd & nd \\
\hline 14. Baía & B & $\mathrm{Ri}$ & $\begin{array}{l}\mathrm{Ec}, \mathrm{Sa}, \\
\mathrm{Hr}, \mathrm{Ps}\end{array}$ & $28.1 \pm 1.9$ & $32.7 \pm 2.5$ & $5.9 \pm 0.2$ & $3.8 \pm 0.9$ & 2.33 & 1.22 \\
\hline 15. Maria Luiza & B & $\mathrm{Ol}$ & Ec & $28.7 \pm 2.5$ & $37.2 \pm 5.1$ & $5.8 \pm 0.4$ & $3.6 \pm 0.1$ & 2.57 & 1.09 \\
\hline 16. Gavião & B & $\mathrm{Ol}$ & Ec & $27.3 \pm 0.8$ & $31.2 \pm 0.1$ & $5.8 \pm 0.6$ & $3.0 \pm 1.3$ & 2.28 & 1.13 \\
\hline 17. Onça & B & $\mathrm{Ol}$ & Ec & 26.6 & 25.8 & 5.1 & 1.2 & 2.37 & 1.16 \\
\hline 18. Paraná & $\mathrm{P}$ & $\mathrm{Ri}$ & $\mathrm{Li}$ & $28.1 \pm 2.8$ & $61.5 \pm 4.4$ & $7.5 \pm 1.1$ & $7.3 \pm 0.8$ & 5.25 & 2.42 \\
\hline 19. Cortado & $\mathrm{P}$ & $\mathrm{Ch}$ & $\mathrm{Ec}, \mathrm{Sa}, \mathrm{Ps}$ & $27.6 \pm 3.5$ & $64.2 \pm 3.8$ & $6.5 \pm 0.2$ & $6.5 \pm 0.9$ & 5.31 & 2.25 \\
\hline 20. Pombas & $\mathrm{P}$ & $\mathrm{Ol}$ & $\mathrm{Ec}$ & $25.2 \pm 2.1$ & $77.4 \pm 27.2$ & $6.1 \pm 0.6$ & $4.3 \pm 0.4$ & 6.12 & 3.09 \\
\hline 21. Carioca & $\mathrm{P}$ & $\mathrm{Cl}$ & $\mathrm{Ec}$ & 22.7 & 69.6 & 5.1 & 2.5 & 6.27 & 2.64 \\
\hline 22. Manezinho & $\mathrm{P}$ & $\mathrm{Ol}$ & $\mathrm{Ec}$ & 26.6 & 58.8 & 6 & 5.4 & 3.50 & 1.83 \\
\hline 23. Leopoldo & $\mathrm{P}$ & $\mathrm{Ol}$ & $\mathrm{Oc}$ & 25.7 & 64.8 & 5.7 & 1.9 & 4.92 & 2.54 \\
\hline 24. Caracu & $\mathrm{P}$ & St & $\mathrm{Li}$ & $25.6 \pm 2.3$ & $52.8 \pm 2.1$ & $6.4 \pm 0.8$ & $6.8 \pm 0.5$ & 3.59 & 2.28 \\
\hline 25. Samambaia 1 & $\mathrm{~T}$ & $\mathrm{Cl}$ & $\begin{array}{l}\mathrm{Mi}, \mathrm{Li}, \\
\quad \mathrm{Sa}\end{array}$ & $25.1 \pm 0.8$ & $30.6 \pm 1.3$ & $6.2 \pm 0.3$ & $8.4 \pm 0.1$ & 1.88 & 1.48 \\
\hline 26. Walter 2 & $\mathrm{~T}$ & $\mathrm{Cl}$ & $\mathrm{Mi}, \mathrm{Ea}$ & $26.3 \pm 26.3$ & $24.6 \pm 10.8$ & $5.8 \pm 0.4$ & $9.4 \pm 1.1$ & 2.11 & 1.31 \\
\hline 27. Curral & $\mathrm{T}$ & $\mathrm{Cl}$ & $\mathrm{Li}$ & $26.3 \pm 3.9$ & $41.0 \pm 3.3$ & $5.6 \pm 0.1$ & $10.6 \pm 3.8$ & 2.04 & 1.52 \\
\hline 28. Banhado & $\mathrm{T}$ & $\mathrm{Cl}$ & $\mathrm{Mi}$ & 28.4 & 31.8 & 5.2 & 3.9 & 1.93 & 1.68 \\
\hline 29. Banhadão & $\mathrm{T}$ & $\mathrm{Cl}$ & Mi & 29.4 & 23.6 & 5.5 & 8.1 & 2.20 & 1.60 \\
\hline 30. Piranha & $\mathrm{T}$ & $\mathrm{Cl}$ & $\mathrm{Li}$ & $26.9 \pm 3.3$ & $31.0 \pm 2.3$ & $5.5 \pm 0.1$ & $7.8 \pm 0.9$ & 1.31 & 1.28 \\
\hline 31. Linda & $\mathrm{T}$ & $\mathrm{Cl}$ & $\mathrm{Li}, \mathrm{Mi}$ & $27.5 \pm 1.8$ & $23.5 \pm 0.2$ & $5.8 \pm 0.2$ & $7.6 \pm 0.1$ & 2.23 & 1.29 \\
\hline
\end{tabular}

$\mathrm{I}=$ Ivinheima, $\mathrm{B}=\mathrm{Baía}, \mathrm{P}=$ Paraná, $\mathrm{T}=$ Taquaruçu, $\mathrm{Cl}=$ closed lake, $\mathrm{Ol}=$ open lake, $\mathrm{Ri}=$ river, $\mathrm{Ch}=$ channel, $\mathrm{St}=\mathrm{stream}, \mathrm{Li}=$ littoral, $\mathrm{Ec}=$ Eichhornia crassipes, Ea $=$ E. azurea, $\mathrm{Ps}=$ Pistia stratiotes, $\mathrm{Sa}=$ Salvinia $\mathrm{spp}, \mathrm{Hr}=$ Hydrocotyle ranunculoides $\mathrm{Oc}=$ Oxycaryum cubense, $\mathrm{Mi}=$ mixed floating, $\mathrm{WT}=$ water temperature, $\mathrm{EC}=$ electrical conductivity, $\mathrm{DO}=$ dissolved oxygen, and nd = not determined.

the inverse was found mainly for the lakes of the Baía system (Figure 2a).

According to the principal component analysis with the November data, higher values of $\mathrm{Mg}, \mathrm{Ca}$, and electrical conductivity discriminated the Paraná from the other systems. The Taquaruçu system was distinguished from the other systems in November by higher values of dissolved oxygen and less acidic water (Figure 2b).

The faunistic survey of the alluvial valley of the upper Paraná River recorded the occurrence of eight Darwinulidae species, belonging to five genera (Table 2 and Figure 3 ). 

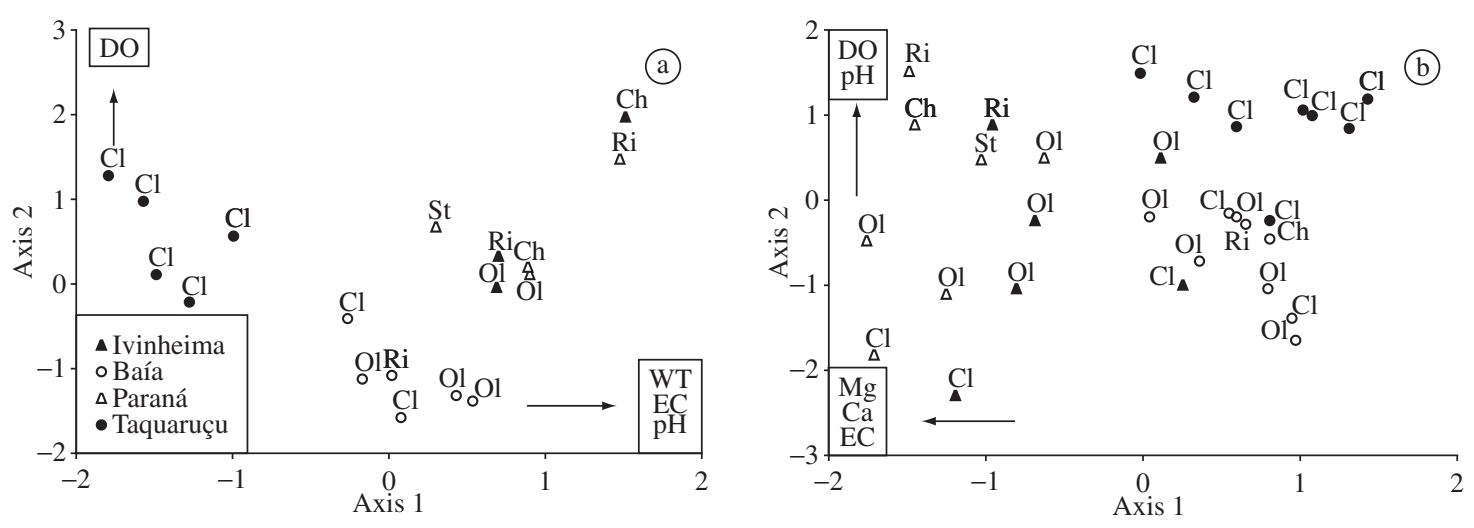

Figure 2. Principal component analysis performed with abiotic limnological data. a) March/July (temperature, $\mathrm{pH}$, dissolved oxygen, and electrical conductivity); and b) November (temperature, $\mathrm{pH}$, dissolved oxygen, electrical conductivity, Ca, and $\mathrm{Mg}$ ). Codes of the abiotic variables and types of habitat are shown in Table 1.

Table 2. Darwinulidae faunistic inventory from the alluvial valley of the upper Paraná River during the study period.

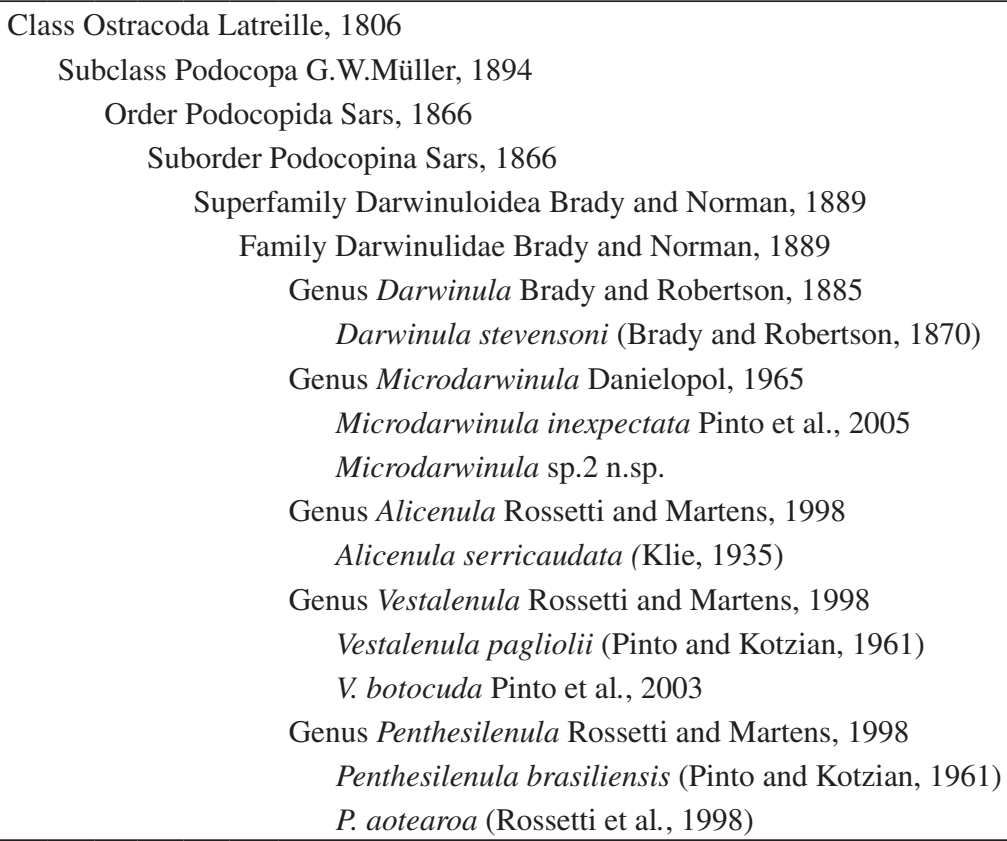

ANOVA results showed significant differences only for the abundance of Alicenula serricaudata when comparing system and habitat. When analyzing different systems, A. serricaudata was significantly more abundant in the lentic habitat (closed and open lake) (Figure 4).

Cluster analysis of 61 samples, based on the composition and abundance of eight species of Darwinulidae in 31 environments, resulted in five associations. The distinct association of types of system and/or habitats characterized each group and was formed by the dominance and/ or occurrence of certain species. In this way, group I was formed by most of the lakes from the Baía, Taquaruçu, and Ivinheima systems. However, two small subgroups were observed. The first one (Ia) was characterized by the dominance of A. serricaudata and Vestalenula pagliolii, and the other group (Ib) by Penthesilenula brasiliensis, as well as the former two species. The other sites were grouped in subsequent interactions with lower similarity, especially in group III, represented by longer branches in the dendrogram. Thus, group II was formed by Taquaruçu system lakes, where only A. serricaudata was abundant. Group III was almost exclusively formed by lotic habitats, such as rivers, channels, and streams. These habitats were characterized by a lower abundance 


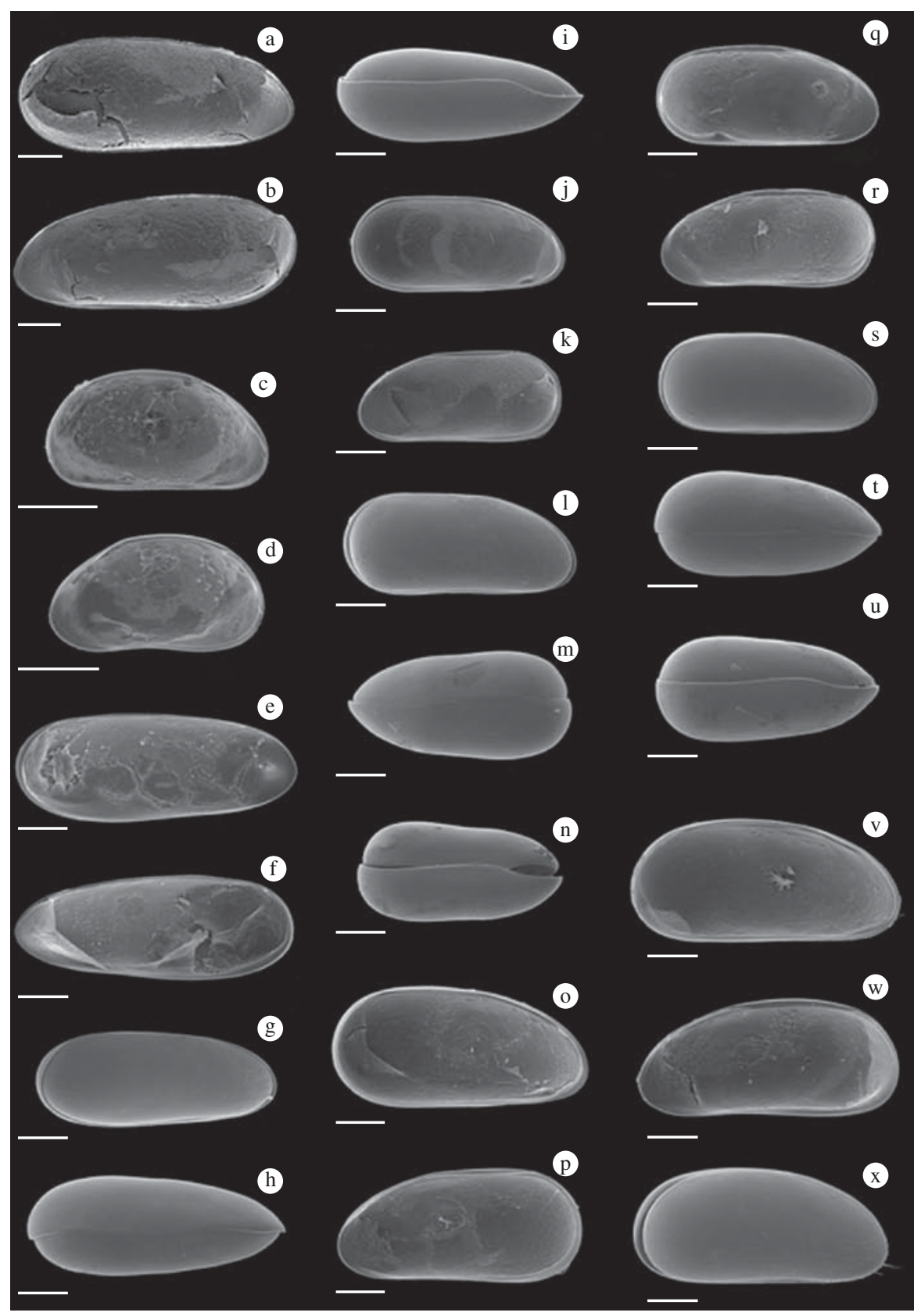

Figure 3. Scanning electron microscopy images of Ostracoda (Darwinulidae) from the alluvial valley of the upper Paraná River. a-b: Darwinula stevensoni; c-d: Microdarwinula sp.2 n.sp.; e-i: Alicenula serricaudata; j-n: Vestalenula pagliolii; o-p: Vestalenula botocuda; q-u: Penthesilenula brasiliensis; v-x: Penthesilenula aotearoa. a, c, e, j, o, q, and v: left valve, internal view; b, d, f, k, p, r, and w: right valve, internal view; g, l, s, and x: carapace, right lateral view; h, m, and t: carapace, dorsal view; i, n, and u: carapace, ventral view. Scale: $100 \mu \mathrm{m}$.

of species which determined the formation of group I (A. serricaudata, V. pagliolii, and P. brasiliensis), besides the occurrence of Vestalenula botocuda and Penthesilenula aotearoa in Caracu stream. Two more small and weak associations were observed. Group IV was represented by habitats where only $V$. pagliolii and
P. brasiliensis occurred, and group V was characterized by the occurrence of Darwinula stevensoni in the Paraná system (Figure 5).

Results from the Mantel multiple test showed that the occurrence and abundance of Darwinulidae were significantly related to type of habitat $(p=0.0025)$ 

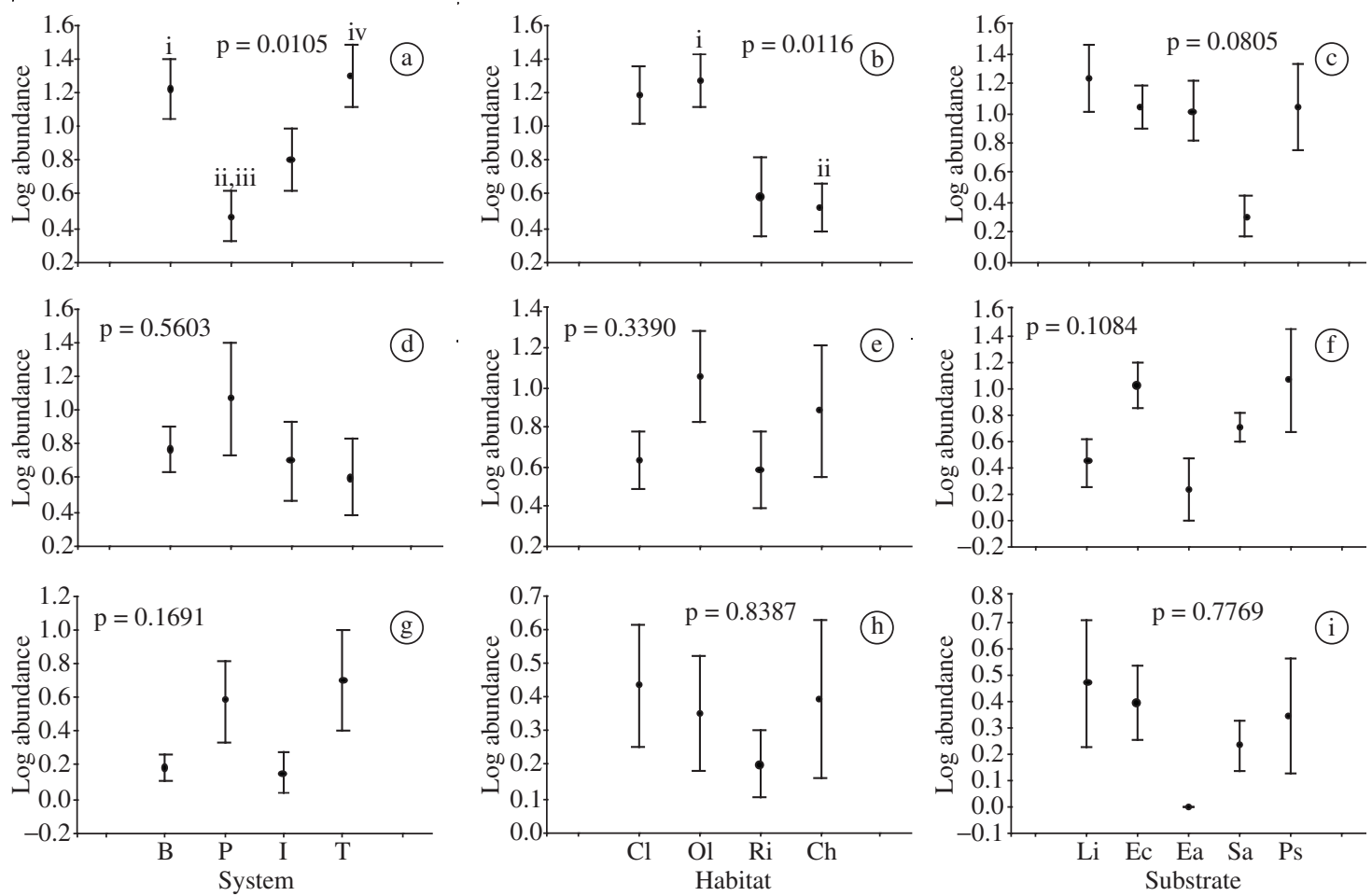

Figure 4. Whiskers plots showing the mean values and standard error of abundance of a-c) A. serricaudata; d-f) V. pagliolii; and g-i) P. brasiliensis. Calculated for different systems, habitats, and substrates from the alluvial valley of the upper Paraná River. Different codes (i, ii, iii, and iv) show significant differences following Tukey tests $(\mathrm{p}<0.05)$. Codes for the types of system, habitat, and substrate are shown in Table 1.

and system $(\mathrm{p}=0.0018)$, but not to substrate type $(\mathrm{p}=0.4881)$ or abiotic limnological variables $(\mathrm{p}=0.3268)$.

\section{Discussion}

Little is known about the biology and ecology of the Darwinulidae. Living species occur in a wide range of habitats from fresh to brackish water, but also in (semi-) terrestrial environments (Pinto et al. 2003; 2004; 2005). Darwinulidae are thought to have low dispersion capacity, as drought resistant stages (present in other ostracod families) have not yet been described for this group (Rossetti et al., 1998). Nevertheless, most darwinulid species have intercontinental distributions; for example, Darwinula stevensoni is cosmopolitan and ubiquitous (Martens et al., 1997). Comparing the present diversity of Cytheroidea and Cypridoidea, the number of genera and species in Darwinuloidea (represented only by the family Darwinulidae) is remarkably low (Martens et al., 1997). In the study region, forty-three species of Cypridoidea were found compared with only 3 species of Cytheroidea (Higuti et al., (in press.))

According to Rossetti and Martens (1998), Martens and Rossetti (2002), and Pinto et al. (2003; 2004; 2005), fifteen darwinulid species have thus far been found in
South America (out of thirty-four species worldwide); half of these, representing all genera, were observed in the alluvial valley of the upper Paraná River.

Despite the fact that some systems could be discriminated by their abiotic limnological variables in the PCA analyses, no significant relationships between these variables and darwinulid species could be found. The type of system and habitat were the main factors driving the composition and abundance of these darwinulid ostracods.

Alicenula occurs in South and Central America and Africa (Martens and Rossetti, 2002). Among the three species known in this genus, only Alicenula serricaudata has thus far been found in Brazil (Martens and Behen, 1994). Vestalenula pagliolii, originally described from South America, has meanwhile been recorded in Europe, exhibiting an intercontinental distribution (Martens et al., 1997). Both species were widely distributed and abundant in the alluvial valley of the upper Paraná River, indicating a wide range of tolerance to environmental factors.

Penthesilenula brasiliensis was found in the benthos and pleuston of the alluvial valley of the upper Paraná River. This species is known to inhabit springs, lakes, and rivers, as well as interstitial (Van Doninck et al., 2003a) and terrestrial habitats (Pinto et al., 2004). This species has been recorded on all continents, except North America and Antarctica (Van Doninck et al., 2003a). 


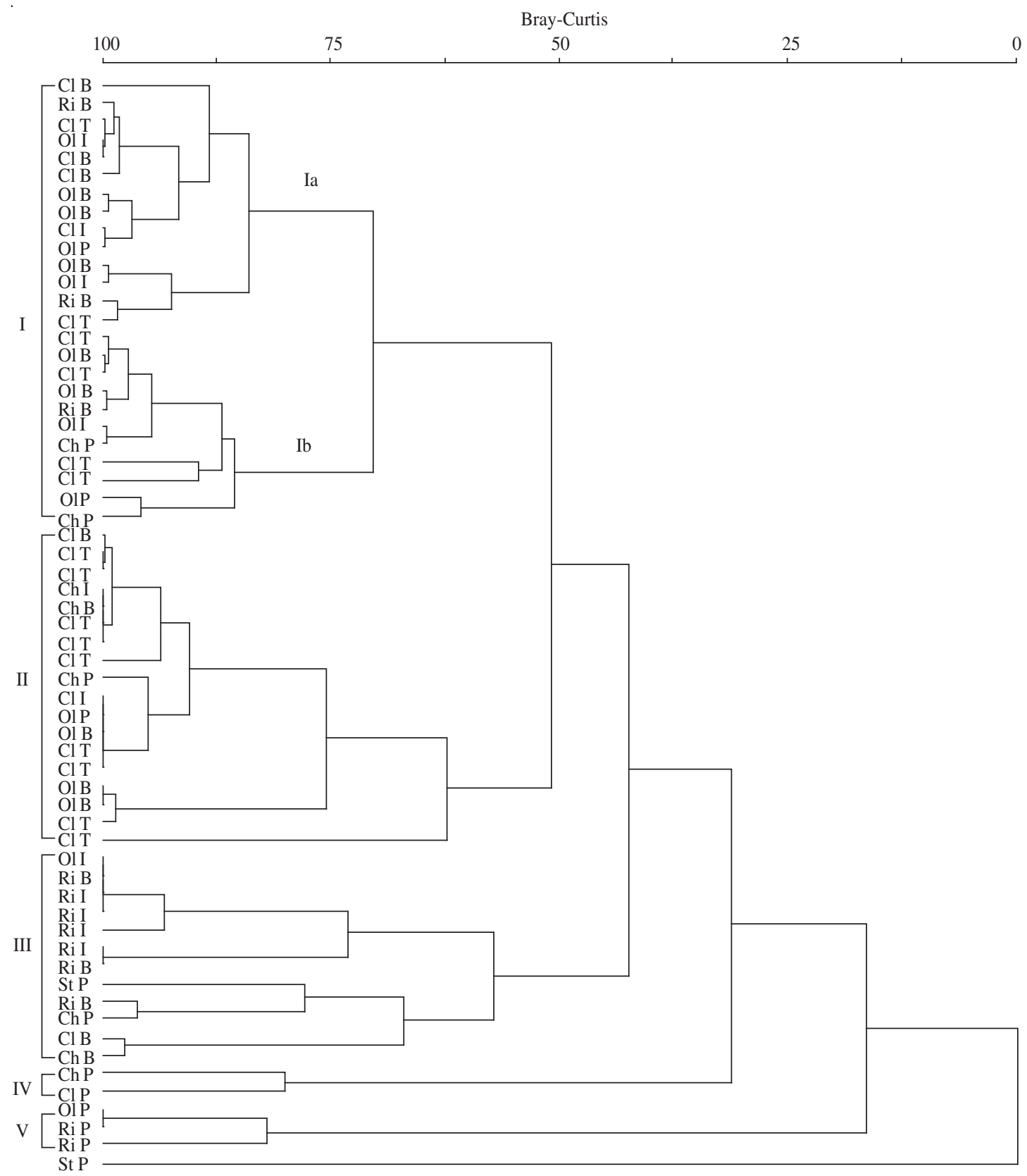

Figure 5. Cluster analysis showing the dissimilarity among sampled habitats in relation to abundance of ostracod fauna of Darwinulidae in the alluvial valley of the upper Paraná River. Codes for the types of system and habitat are shown in Table 1.

In Brazil, $P$. brasiliensis was recorded from fresh and brackish waters of Rio Grande do Sul State (Pinto and Kotzian, 1961; Würdig and Freitas, 1988; Würdig et al., 1990; Albertoni and Würdig, 1996), in pleuston from Mato Grosso do Sul State - Pantanal (Rocha and Por, 1998), and in a terrestrial environment from São Paulo State (Pinto et al., 2004).

Darwinula stevensoni occurred only in two environments of the alluvial valley of the upper Paraná River (open lake and Paraná River), and only a few specimens were found. In several other regions of the world, this species has been found in large numbers in several localities (McGregor, 1969; Ranta, 1979; Martens and Tudorancea, 1991; Rossi et al., 2002; Van Doninck et al., 2003). The low occurrence and abundance of $D$. stevensoni in the alluvial valley of the upper Paraná River could result from the fact that sampling was done only twice during an annual cycle. If the species occurs seasonally, it would 
be easy to miss it. However, this does not seem to be a consistent hypothesis. D. stevensoni has a long life cycle (1 to 4 years) in temperate regions (McGregor, 1969; Ranta, 1979; Van Doninck et al., 2003b), but in subtropical regions, temperatures are higher and D. stevensoni likely have a relatively short life cycle, with continuously producing generations during an annual cycle. According to McGregor (1969), the reproductive potential of this species is related mainly to temperature, and the maturation of D. stevensoni occurs during months with higher temperatures. Since the water temperatures during sampling periods varied from $22.7^{\circ} \mathrm{C}$ to $31.3^{\circ} \mathrm{C}$, seasonality in the life cycle of this species is unlikely. Martens and Tudorancea (1991) demonstrated that this species was perennial in a tropical Ethiopian lake, but also found that this species avoided places with the highest temperatures.

It is also known that $D$. stevensoni prefers oxygenated environments (Martens and Tudorancea, 1991) to aerate its eggs and juveniles which are carried in a brood pouch inside the carapace. Nevertheless, significant tolerance for oxygen depletion by adults has been demonstrated (Rossi et al., 2002). In the present study, this species was found only in Paraná River, which had a higher content of dissolved oxygen, and in one marginal lake associated with this river. The sampling in this latter location (Pombas lake) was performed at the mouth of the lake, almost on the Paraná River banks. Therefore, this species seems to be limited to the more oxygenated water of the Paraná River.

Vestalenula botocuda and Penthesilenula aotearoa only occurred in Caracu stream, an environment with lotic characteristics and sandy sediment. V. botocuda was recently described in a Brazilian semi-terrestrial environment (Pinto et al., 2003), while P. aotearoa was first described in a small marsh near a stream in New Zealand, and later found in semi-terrestrial and terrestrial habitats in Brazil (Pinto et al., 2004). P. aotearoa is thus a species with intercontinental distribution.

The genus Microdarwinula was long thought to be monospecific, with Microdarwinula zimmeri as the only species (Rossetti and Martens, 1998). Recently, Microdarwinula inexpectata was discovered in semi-terrestrial habitats in Brazil (Pinto et al., 2005). M. zimmeri has a wide geographical distribution, and South America is the only continent besides Antarctica where this species has thus far not been found (Martens and Behen, 1994; Martens et al., 1998; Rossetti and Martens, 1998). According to Pinto et al. (2005), there is the possibility of finding $M$. inexpectata in other Brazilian localities and in other South American countries. This fact is here confirmed by the presence of $M$. inexpectata in a closed lake from the Taquaruçu system. Moreover, we found one specimen of Microdarwinula distinct from the known species, which was named Microdarwinula sp. 2 n.sp.

The composition and abundance of ostracods, including darwinulids, can be different between benthic communities and those associated with aquatic macro- phytes (Würdig and Freitas, 1988; Würdig et al., 1990). Darwinulid ostracods from Gentil lagoon, a brackish environment in south Brazil, were abundant in the benthos, with V. pagliolii being the most abundant species; in the aquatic macrophyte stands, the abundance of darwinulids was lower and was represented mainly by $D$. stevensoni. Besides the importance of substrate type on ostracod distribution in Gentil lagoon, the salinity also exerted influence on species distribution (Albertoni and Würdig, 1996).

In the present study, all investigated habitats were freshwater, and the results indicate the absence of preference by darwinulid ostracods for different substrate types. Higher darwinulid taxon richness was observed in littoral benthos of the Paraná system, mainly in the lotic habitat. Such habitats are more directly influenced by the hydrodynamics of the river, including large flood events. It would thus appear that regional hydrodynamics act more strongly on darwinulid ostracods than local limnological characteristics.

Acknowledgements - Julien Cillis (Brussels, Belgium) offered technical assistance with the scanning electron micrographs; the researchers of the Laboratory of Limnology of Nupélia are thanked for their assistance in measuring abiotic variables; we thank Jaime Luiz Lopes Pereira (University of Maringá) for technical help with the map and the plate; Dirceu Galli (University of Maringá) is acknowledged for help with chemicals. This research was supported by CNPq (proc. 472434/03-9), CNPq/ PELD, and Nupélia.

\section{References}

AGOSTINHO, AA. and ZALEWSKI, M., 1996. A planície alagável do alto rio Paraná: importância e preservação. (Upper Paraná River Floodplain: Importance and Preservation). Maringá: EDUEM. 100p.

ALBERTONI, EF. and WÜRDIG, NL., 1996. Comunidade de ostracodes associada à macrófitas aquáticas na lagoa do Gentil, Tramandaí, RS. Acta Limnologica Brasiliensia, vol. 8, p. 103-114.

BUTLIN, RK. and GRIFFTHS, HI., 1993. Ageing without sex? Nature, vol. 364, p. 680 .

HIGUTI, J., LANSAC-TÔHA, FA., VELHO LFM. and MARTENS, K. (in press.). Biodiversity of non-marine ostracods (Crustacea, Ostracoda) in the alluvial valley of the upper Paraná River, Brazil. Brazilian Journal of Biology.

HIGUTI, J. and TAKEDA, AM., 2002. Spatial and temporal variation in densities of chironomid larvae (Diptera) in two lakes and two tributaries of the upper Paraná River floodplain, Brazil. Brazilian Journal of Biology, vol. 62, no. 4B, p. 807-818.

LANSAC-TÔHA, FA., VELHO, LFM., HIGUTI, J. and TAKAHASHI, EM., 2002. Cyclopidae from high Paraná River floodplain, Brasil. Brazilian Journal of Biology, vol. 62, no.1, p. $125-133$.

MARTENS, K., 1998. Diversity and endemicity of recent nonmarine ostracods (Crustacea, Ostracoda) from Africa and South America: a faunal comparation. Vereinigung Internationale füer Theoretische und Angewandte Limnologie Verhandlungen, vol. 26, p. 2093-2097.

MARTENS, K. and TUDORANCEA, C., 1991. Seasonality and spatial distribution of the ostracods of Lake Zwai, Ethiopia 
(Crustacea: Ostracoda). Freshwater Biology, vol. 25, no. 2, p. 233-241.

MARTENS, K. and BEHEN, F., 1994. A checklist of the nonmarine ostracods (Crustacea, Ostracoda) from the inland waters of South America and adjacent islands. Travaux Scientifiques $d u$ Musée d' Histoire naturelle de Luxembourg, vol. 22, p. 1-81.

MARTENS, K., ROSSETTI, G. and FUHRMANN, R., 1997. Pleistocene and recent species of the family Darwinulidae Brady and Norman, 1889 (Crustacea, Ostracoda) in Europe. Hydrobiologia, vol. 357, p. 99-116.

MARTENS, K., WÜRDIG, NL. and BEHEN, F., 1998. Maxillopoda: non-marine Ostracoda. In: YOUNG, PS. (Ed.). Catalogue of Crustacea of Brazil. Rio de Janeiro: Museu Nacional, p. 45-65.

MARTENS, K. and ROSSETTI, G., 2002. On the Darwinulidae (Crustacea: Ostracoda) from Oceania. Invertebrate Systematics, vol. 16 , no. 2, p. 195-208.

MARTENS, K., ROSSETTI, G. and HORNE, DJ., 2003. How ancient are ancient asexuals?. Proceedings of the Royal Society of London B Biological Sciences, vol. 270, no. 1516, p. 723-729.

MARTENS, K., ROSSETTI, G., BUTLIN, RK. and SCHÖN, I., 2005. Molecular and morphological phylogeny of the ancient asexual Darwinulidae (Crustacea, Ostracoda). Hydrobiologia, vol. 538, p. 153-165.

McGREGOR, DL., 1969. The reproductive potencial, life history and parasitism of the freshwater ostracod Darwinula stevensoni (Brady and Robertson). In: Neale, JW. (Ed.). The taxonomy, morphology and ecology of recent Ostracoda. Edinburgh: Oliver \& Boyd. p. 194-221.

PINTO, ID. and KOTZIAN, CB., 1961. Novos ostrácodes da família Darwinulidae e a variação das impressões musculares. Boletim do Instituto de Ciências Naturais da Universidade do Rio Grande do Sul, vol. 11, p. 5-64.

PINTO, RL., ROCHA, CEF. and MARTENS, K., 2003. On two new species of the genus Vestalenula Rossetti and Martens, 1998 (Crustacea, Ostracoda, Darwinulidae) from semi-terrestrial habitats in São Paulo State (Brazil). Zoological Journal of the Linnean Society, vol. 139, no. 2, p. 305-313.

2004. On the genus Penthesilenula Rossetti and Martens, 1998 (Crustacea, Ostracoda, Darwinulidae) from (semi-) terrestrial habitats in São Paulo State (Brazil), with the description of a new species. Journal of Natural History, vol. 38 , no. 20 , p. $2567-2589$.

2005. On the evolution of the genus Microdarwinula Danielopol, 1968(Ostracoda, Darwinulidae) with the description of a new species from semi-terrestrial habitats in São Paulo State (Brazil). Crustaceana, vol. 78, no. 8, p. 975-986.

RAINWATER, FH. and THATCHER, LL., 1960. Methods for collection and analysis a water samples. Washington: United States Government Printing Office, 39p.

RANTA, E., 1979. Population biology of Darwinula stevensoni (Crustacea, Ostracoda) in na oligotrophic lake. Annales Zoologici Fennici, vol. 16, no. 1, p. 28-35.

ROCHA, CEF. and POR, FD., 1998. Preliminary comparative data on the fauna of the pleuston in the southern Pantanal, Brazil, with emphasis on the microcrustaceans. Vereinigung Internationale füer Theoretische und Angewandte Limnologie Verhandlungen, vol. 26, p. 2137-2140.
ROSSETTI, G. and MARTENS, K., 1996. Redescription and morphological variability of Darwinula stevensoni (Brady and Robertson, 1870) (Crustacea, Ostracoda). Bulletin de L'Institut Royal des Sciences Naturelles de Belgique, Biologie, vol. 66, p. 73-92.

1998. Taxonomic revision of the recent and holocene representatives of the Family Darwinulidae (Crustacea, Ostracoda), with a description of three new genera. Bulletin de L'Institut Royal des Sciences Naturelles de Belgique, Biologie, vol. 68 , p. 55-110.

ROSSETTI, G., EAGAR, SH. and MARTENS, K., 1998. On two new species of the genus Darwinula (Crustacea, Ostracoda) from New Zealand. Italian Journal of Zoology, vol. 65, p. $325-332$

ROSSI, V., TODESCHI, EBA., GANDOLFI, A., INVIDIA, M. and MENOZZI, P., 2002. Hypoxia and starvation tolerance in individuals from a riverine and a lacustrine population of Darwinula stevensoni (Crustacea: Ostracoda). Archiv fuer Hydrobiologie, vol. 154, no. 2, p. 151-171.

SCHÖN, I., MARTENS, K., Van DONINCK, K. and BUTLIN, RK., 2003. Evolution in the slow lane: molecular rates of evolution in sexual and asexual ostracods (Crustacea: Ostracoda). Biological Journal of the Linnean Society, vol. 79, no. 1, p. 93-100.

SMITH, RJ., KAMIYA, T. and HORNE, DJ., 2006. Living males of the "ancient asexual" Darwinulidae (Ostracoda: Crustacea). Proceedings of the Royal Society of London B Biological Sciences, vol. 273, no. 1593, p. 1569-1578.

SOUZA FILHO, EE. and STEVAUX, JC., 2004. Geology and geomorphology of the Baía-Curutuba-Ivinheima river complex. In: Thomaz, SM., Agostinho, AA. and Hahn, NS. (Eds.). The upper Paraná River and its floodplain: physical aspects, ecology and conservation. Leiden: Backhuys Publishers, p. 1-29.

THOMAZ, SM., AGOSTINHO, AA. and HAHN, NS., 2004. The upper Paraná River and its floodplain: physical aspects, ecology and conservation. Leiden: Backhuys Publishers, 393p.

VAN DONINCK, K., SCHÖN, I., MAES, F., DE BRUYN, L. and MARTENS, K., 2003a. Ecological strategies in the ancient asexual animal group Darwinulidae (Crustacea, Ostracoda). Freshwater Biology, vol. 48, no. 8, p. 1285-1294.

VAN DONINCK, K., SCHÖN, I., MARTENS, K. and GODDEERIS, B., 2003b. The life-cycle of the asexual ostracod Darwinula stevensoni (Brady and Robertson, 1870) (Crustacea, Ostracoda) in a temporate pond. Hydrobiologia, vol. 500, p. 331-340.

VELHO, LFM., LANSAC-TÔHA, FA., TAKEDA, AM., HIGUTI, J. and SOUZA FRANCO, GM., 2001. Structure and dynamics of Cyclopidae associated with aquatic macrophytes in two lotic environments of the upper Paraná River floodplain, Brasil. Acta Scientiarum, vol. 23, no. 2, p. 349-356.

WAGNER, R., 1976. Sampling and sample preparation. Fresenius Journal of Analytical Chemistry, vol. 282, no. 4, p. 315-321.

WÜRDIG, NL. and FREITAS, SMF., 1988. Distribuição espacial e temporal da comunidade de ostrácodes na lagoa emboaba, Rio Grande do Sul, Brasil. Acta Limnologica Brasiliensia, vol. 2, p. $677-700$

WÜRDIG, NL., FREITAS, SF. and FAUSTO, IV., 1990. Comunidade de ostracodes associada ao bentos e macrófitas aquáticas da lagoa do Gentil, Tramandaí, Rio Grande do Sul. Acta Limnologica Brasiliensia, vol. 3, p. 807-828. 